\title{
Emancipated perfectionism - or, In praise of dreaming
}

\author{
Clare Woodford
}

[T] he issues raised in these films concern the difficulty of overcoming a certain moral cynicism, a giving up on the aspiration to a life more coherent and admirable than seems affordable after the obligations and compromises of adulthood begin to obscure the promise and dreams of youth and the rift between public demands and private demands comes to seem unbridgeable. ${ }^{1}$

In the logic of emancipation ... there is always a third thing ... The same applies to performance. It is not the transmission of the artist's knowledge or inspiration to the spectator. It is the third thing that is owned by no one, whose meaning is owned by no one, but which subsists between them, excluding any uniform transmission, any identity of cause and effect. ${ }^{2}$

I imagine that democracy without dreams would be a rather dull place. If we accept Dienstag's argument that "the time of cinema is a dreamtime," then I would suggest that dreaming, both with and without films, is not merely a pleasurable distraction but a valuable pastime for democratic citizens. I take this stance in response to Joshua Dienstag's brilliant "remake" of Rousseau's Lettre à M. d'Alembert in the form of his "Letter to M. Cavell." There is much to ponder in this rich

Stanley Cavell, Cavell on Film, edited by W. Rothman (Albany, NY: State University of New York Press, 2005) p. 11.

2 Jacques Rancière, "The Emancipated Spectator," in The Emancipated Spectator, translated by Gregory Elliott (London and New York: Verso, 2009) pp. 14-15. 
and thoughtful letter, which argues contra Cavell that, although enjoyable, film does not teach us "what it is to be better" and that to claim that it does and that it is therefore beneficial for democracy is "dangerous," (pp. 75, 10). Although I admire much of Dienstag's analysis, I am bound to defend film as a possible source of fruitful and inspiring dreams and hence seek not to go so far as to champion film-watching as a necessary democratic activity, but merely to suggest that watching films can be beneficial for democracy. In making this argument I wish to emphasize that this requires us to focus our emphasis less on the vision of the world (or beyond) that is portrayed in film and more on the relationship between the film and its audience.

I will begin my response by briefly examining differing alternative interpretations of The Philadelphia Story to defend its use as a fruitful exemplar for my understanding of democratic relationships. I refer to my own interpretation, not in challenge to Dienstag or Cavell, but to engage them in conversation, and indeed will then draw on Cavell's work on exemplarity to remind us that, for moral perfectionism, the act of interpreting is prioritized over the interpretation. By, then, reading this claim alongside the work of Jacques Rancière, I will emphasize his claim that spectators are always already engaged in such interpretation, but too often do not trust the legitimacy or authority of their own interpretation over that of others. Rancière suggests that in learning to accept one's own authority, and in being recognized as doing so, the role of spectator is emancipated from the unequal hierarchies of knowledge, giving us a more democratic model of the citizen. I will consequently argue that we can read Cavell and Rancière together to establish an idea of an emancipated perfectionist society in which citizens as spectators are seen to acknowledge the authority of their own thoughts. With this in mind, I will turn back to Emerson to discuss how the perfectionist commitment to self-reliance is cultivated through "aversive thinking" and the positive role of dreaming within this. Finally, I will explore Dienstag's wider claim about the value of films for democracy in general. Here I suggest a symbiotic relationship between eros and stability and defend moral perfectionism as the compass with which we can 
navigate the winding path between the anarchy of eros and the order of stability to enable us to draw on both without losing the other.

Yet, as I begin, it is important to note that I admire Dienstag's vision of democracy as a quest. On this quest he envisages that we "meet each other as citizens and share a moment without the associated narrative dominating or captivating us and yet embracing the open-endedness of our association, its contingency and its dangers" (p. 81). It may perhaps seem strange that this quest is not very different from the way I have always conceived Cavell's work on perfectionism, as an unending atelological search in the company of others, each for our unattained self that always remains one step ahead of us on the path of life. ${ }^{3}$ Because of this, I see Dienstag's essay as a puzzle to solve, forcing me to return throughout this chapter to how it is that his reading takes Cavell's work on film to give us something rather different from this quest.

\section{Two models of exemplarity}

In much of Cavell's writing on film he seeks to show us that the protagonists of the films he terms "remarriage comedies" live a form of perfectionism that he upholds as desirable for contemporary democratic society: moral perfectionism. However, there appear to be two ways in which we can interpret exemplarity in Cavell's writing. One, I suggest, may be more valuable in helping us understand the perfectionist register than the other.

The first type of exemplarity is found in the understanding that the central couple in the remarriage comedies exhibit desirable qualities, as if Cavell is then indicating that we would do well to imitate them. ${ }^{4}$ Indeed,

3 See Stanley Cavell, Pursuits of Happiness: The Hollywood Comedy of Remarriage (Cambridge, MA: Harvard University Press, 1981), p. 29, where he claims that life is a journey, and Stanley Cavell, Conditions Handsome and Unhandsome: The Constitution of Emersonian Perfectionism (Chicago, IL, and London: University of Chicago Press, 1990), p. 56, where he emphasizes the ateleological commitment of perfectionism.

4 As may be interpreted by his claim that the films can "instruct" us (Cavell, Pursuits of Happiness, p. 7). 
it is this model that Dienstag is concerned about, suggesting that, for Cavell, The Philadelphia Story "provides us with an exemplar of perfection, which may lead us to perfect ourselves." Dienstag opines that this is a "dangerous contention." Instead, he suggests that our attraction to this film "reveals our degraded condition and that it is in a sense this condition that binds us to it. What perfection the film embodies remains, therefore, out of reach for us and, as such, a hazard rather than a telos" (p. 10).

In contrast to what he finds in Cavell - the idea that this film shows us how to be more perfect democratic citizens - Dienstag's counter-reading comprises the following argument: The Philadelphia Story provides us with a model of behavior that hypocritically seeks to keep the difficulties and troubles of life private, hiding them behind a public veneer of perfection; it reveals to us that, for the protagonists, publicity and therefore democratic scrutiny is dirty and voyeuristic and, therefore, if their behavior and opinions were copied it would lead us to a questionable type of happiness that is far from suitable for a democratic way of life. Enjoyable the film may be, but exemplary of ideal democratic relationships it is not. To take it as so is at best misleading and at worst dangerous.

Consequently, although Cavell has claimed that we have a responsibility to be happy in a democracy, ${ }^{6}$ Dienstag is concerned that the happiness of the film is the happiness of a masochistic voyeur who finds Spy magazine in their hands at the end of the film. Thus, to argue that this film is an example of a more perfect democracy is shown to propagate a myth: democracy is capable of synthesizing our private loves with our public responsibilities in a way that leads to happiness only if we accept that this happiness depends on us denying the unruly extent of eros, and therefore pretending that we are happy when in actual fact we have to repress our desires. Thus, after this reading, we are left rather confused about the so-called happiness which Cavell wishes us to pursue.

See above, italics added.

6 Cavell, Cavell on Film, p. 348. 
In contrast, I wish to share a third interpretation of The Philadelphia Story that incorporates elements of both Cavell's and Dienstag's readings. Let us begin with Dienstag's concern that the hypocrisy of the public wedding is different from what he sees to be the "true" state of affairs behind the facade: the pretense that we can happily control our erotic attachments, when in actual fact we cannot. I would suggest that if the couple had not opted for a traditional white wedding then this would uphold the idea that a second wedding is in some way inferior to the first: that the "failure" or imperfection of the first has tarnished the couple and that society no longer deems them capable of the lofty ideals and control of eros implied by a traditional marriage. However, Tracy and Dexter's wedding is, as Dienstag observes, like a rerun of the first, with lots of guests, crystal and lace decorations, Wagner's bridal march and the bride in a traditional white wedding dress. I took this to imply that Tracy and Dexter are having a go at the whole thing again, in all its romantic glory. Acknowledging, at least to the film's audience if not to the wedding guests, that, despite social pretenses, behind every wedding - not just second or third weddings - is the reality of imperfection, contingency and possible heartbreak and infidelity. The wedding scene appears as a challenge and reinterpretation of the traditional view of marriage, seeking to reform the very view of the institution itself, not merely propose an alternative. If, conversely, Tracy and Dexter had opted for a smaller "second" wedding, the film would be condoning the social idea that there are two types of wedding and therefore two types of possible relationship: the traditional white wedding for perfect relationships and the non-traditional or smaller wedding for imperfect relationships. This contains within it the assumption that perfect relationships can and do exist. Instead, the film shows that all marriages are imperfect despite the promises we make, and thereby acknowledges the contingency in every promise: the ability to fail and the ability to try again, expressed in the bittersweet phrase "for better for worse." The human condition is to aspire to perfection whilst always falling short. This, for me, was the beauty of this hopelessly romantic, yet wonderfully idealistic finale. 
Yet, alongside these initial concerns, Dienstag observes throughout The Philadelphia Story the repetition of the claim that "what is necessary to be fully human is 'to have some regard for human frailty," yet then notes that "naming a disease makes us no healthier," (p. 75). This is interesting, because it reveals Dienstag's more cynical view: his disappointment in the human condition and his desire to act to overcome this. But, for Cavell, perfectionism is about accepting (to the point of happiness) our frailty at the same time as seeking a little more strength. ${ }^{7}$ It is about smiling at the challenge that adversity brings rather than recklessly seeking to eliminate it, for it is this adversity that denotes our humanity; we cannot overcome it, but we can face it head on. Such a realization may understandably provoke cynicism or even despair, but Cavell's strategy is not to give in to this, but to instead be happy that we have the chance to engage in the challenge, and to enjoy the journey. Consequently, at this point I would claim that The Philadelphia Story is not so much about hypocrisy and privacy, but about the acceptance of imperfection without accompanying this acceptance with cynicism. Instead, it finishes on a positive note, that we can always work to attain something better. Thus, the couple have a traditional wedding ceremony not in spite of their acknowledgment of their imperfection and the contingency of the relationship, but because of this: to reveal to the viewer the contingency behind every agreement, ceremony and promise, and the fact that acknowledging this is $\mathrm{OK}$ and need not undermine its seriousness, but instead underlines the need for all involved to continue to accept their unavoidable implication in the relationship, and the perfectionist requirement to work at it continually, summed up in Cavell's phrase "as if all genuine marriage is remarriage." ${ }^{\text {Th }}$ Thus, perfectionism, as Cavell explains in the quote that opens this chapter, is about overcoming the usual cynical reaction to human imperfection with a commitment to seeking happiness regardless.

Cavell, Conditions Handsome and Unhandsome, p. 110.

8 Cavell, Conditions Handsome and Unhandsome, p. 104. 
Furthermore, with respect to Dienstag's concern about the voyeurism of the viewer-subject, the uncomfortable "magazine photograph" kiss at the end of the film alerted me, as viewer, to every audience's voyeurism, but not to simply reward it, as in Dienstag's reading. In showing Hepburn as uncomfortable it emphasized that it is our voyeuristic desire to watch and comment on others' lives that puts pressure on others to not admit their imperfections and to sweep their troubles under the carpet of privacy. From the early discussion of Spy magazine, through the comments about Tracy being a "goddess" to this final frame, the film reveals the damage that we "the public" do through our taste for tabloid scandal and celebrity worship. We set up heroes to live our lives for us and then wait like vultures for them to fall, rather than attend to our own troubles. The moral of this viewer relationship could be interpreted as implying that our desire and enjoyment to be the passive viewer rather than the active critical thinker invests our political and civil ceremonies with more importance and permanence than they should really have. Our dysfunctional society forces the protagonists to seek privacy (whilst they may be wrong to do so, this becomes more understandable given such a society). If we readjust the balance so that we focus more on our own lives than those of others then perhaps we can all admit our imperfections a little more and loosen the pressure we all feel to keep our troubles private and put on or receive a show of perfection intended to impress others. So, although Dienstag is right to suggest that in today's society we may expect that the visibility of our frailty "weakens the bonds of union which they are pledged to uphold," (p. 20) it strikes me that a perfectionist society would be one in which such expectations are lowered and that visibility of frailty could strengthen such bonds, revealing that their maintenance requires constant attention and thereby inspires people's motivation. In the same way that any grand structure built on slender foundations would likely take our breath away, recognition of frailty could increase our awe.

In this interpretation, Cukor's film inspired me to reflect upon the extent to which we could engage in our relationships, both intimate and political, in an open non-finite manner to live in a forgiving and 
open way in our lives, as the protagonists learn to do in theirs, rather than to focus on watching and gossiping about others. This involves a much deeper interpretation of democratic relations than that found in much political thought today. With relation to the political analogy discussed by Dienstag, the moral would be to stop watching others making a constitution and then limit our involvement to merely moaning about it, but to get involved in making our own constitution, to push democracy to a fuller definition. Hence, The Philadelphia Story's ending seems to moralistically say that we should not have enjoyed it in the way that we did (letting it just wash over us as entertainment), that we need to work on ourselves to interact more actively with everything around us to learn from the relationships rather than just watching them. In this way, I interpreted the film as seeking to inspire the viewers to think more carefully for themselves. Yet, this is a different model of exemplarity from that encountered above, for it does not imply that the protagonists are to simply be copied or imitated in any particular way, but instead it inspires us to be more active viewers and citizens ourselves.

Indeed, if we return to Cavell for a moment, we find a more predominant role for this second model of exemplarity as inspiration in the sense of inspiring one's own thoughts and responses ${ }^{9}$ - rather than the previous imitation model. In the essay "Aversive Thinking," Cavell draws on Nietzsche's paraphrasing of Emerson's work on the exemplar relation. In Nietzsche's talk of consecrating oneself to culture and attaching one's heart to great men, ${ }^{10}$ Cavell reads the imperative to be inspired by one's heroes, not to copy them, but in a way that leads us to hate one's own meanness and be inspired by the way that these great men lived for themselves, and therefore to aim to do the same, to take their work as stimulus for our own. ${ }^{11}$ Cavell also notes the call in Emerson to never be content with oneself and always to be

9 Not in the sense of a film director controlling inspiration, merely as impulses that stimulate thought.

${ }^{10}$ Cavell, Conditions Handsome and Unhandsome, p. 53.

11 Cavell, Conditions Handsome and Unhandsome, pp. 49-54. 
inspired by others, not to do as they do, but to live for oneself: "Each philosopher, each bard, each actor has only done for me, as by a delegate, what one day I can do for myself." ${ }^{12}$ This model of exemplarity is not a model of imitation, but one of inspiring a passive observer to become the active doer.

It is necessary to note at this point that although Dienstag does not seek to distinguish the two models of exemplarity discussed in this chapter, and although he does at times refer to film "instructing" or "teaching" us, at other times he seems to wish to focus more generally on the interplay between possible interpretations. Without explicitly acknowledging this distinction between the two models of exemplarity, and in some ways bound to the first through his invocation of Rousseau, Dienstag seems to predominantly read Cavell's use of exemplars in the imitative model. In this sense, then, he is right to question Cavell's reading of The Philadelphia Story, and many of the other remarriage comedies that Cavell draws upon, because, despite my interpretation, the protagonists do seem to portray characteristics that may not be desirable or possible for all people in a democracy, such as a privileged, often aristocratic upbringing, privacy from the public gaze, a life together away from society, a life of leisure, and in many cases the patronizing and subjection of the female role by the male. Nevertheless, more often than not, when Cavell talks about the way that films interact with our society, it is this deeper understanding of exemplarity that he seems to be drawing on. ${ }^{13}$ But, as seen in Dienstag's interpretation, Cavell does not often make this explicit, instead perhaps assuming his readers will already be aware of his discussion of exemplarity in Conditions Handsome and Unhandsome, and does not always practice a completely consistent application of this model himself. It is thus maybe rather too easy to read the imitation model into his work, since this has always

12 Cavell, Conditions Handsome and Unhandsome, p. 54.

${ }^{13}$ Indeed, I cannot find any place in Cavell's writing where he is explicitly drawing on the first model, although at times it may be implied. In particular, in Cities of Words he notes how these films "manifest" something to us, rather than evoke us to imitate (Cambridge, MA, and London: Belknap/Harvard University Press, 2004), p. 9. See also note 35 below. 
been so dominant in Western thought. ${ }^{14}$ According to this model, the spectator is educated (whether for good or ill) by that which he sees portrayed, because it is assumed he will seek to imitate it (or, in the situation of a negative example, to refrain from imitating it). Indeed, such a view appears to be echoed in Cavell's invocation of "good film" in the quote chosen by Dienstag at the opening of his letter.

However, I am not discussing this in order to take a side in history with Voltaire and d'Alembert against Plato and Rousseau for, upon examination, we see that d'Alembert's claim also invokes the imitation model, believing that, with better regulation concerning both the conduct of actors and the theaters themselves, the presence of theater in Geneva could have a moralizing influence on society. ${ }^{15}$ Instead, I want to draw upon Rancière's essay "The Emancipated Spectator," in which Rancière claims that both sides in this debate are based on an inaccurate picture of the relationship between art and the spectator. Even with regard to recent postmodern forms of art, Rancière suggests that artists "always assume that what will be perceived, felt, understood is what they have put into their dramatic art or performance,"16 and thus think that they can control to some extent the effect of their art upon its audience.

In contrast, despite the aspiration of artists, playwrights and writers, Rancière suggests in the epigraph above, that they can never control the influence of their art because the contingency of meaning cannot be controlled once it is let loose into the social world. ${ }^{17}$ Thus, the

${ }^{14}$ In particular, in relation to the impact of art on democracy, Plato's concerns about the negative effects of art on political society, voiced by Socrates in The Republic, filtered down via Rousseau into the concerns of newly emerging representative democracies of the modern age in the writings of eighteenth-century French Revolutionaries (Susan Maslan, Revolutionary Acts: Theatre, Democracy and the French Revolution (Baltimore, MD: The Johns Hopkins University Press, 2005) esp. ch. 2). From there it can be traced into the ideas espoused by radical playwrights who seek to orchestrate their audience's response by promoting "good" art over "bad" art, perhaps most familiar in the writings of Brecht, but also more recently in Augusto Boal, Theatre of the Oppressed (London: Pluto Press, 2000).

15 D'Alembert, cited by Jean-Jacques Rousseau, Politics and the Arts, translated by Alan Bloom (Ithaca, NY: Cornell University Press, 1968) p. 4.

16 Rancière, “The Emancipated Spectator," p. 14.

17 Rancière, "The Emancipated Spectator," pp. 14-15. 
aforementioned imitative model of the relation between art and its spectator is revealed as illusory: the relation of imitation that so concerned Rousseau and Voltaire from different perspectives is thereby revealed to be a useful myth to propagate the status of intellectuals (philosophers, playwrights, authors, etc.) as society's interpreters. ${ }^{18}$ Instead, according to Rancière, such a role is unnecessary, as all spectators already do and will continue to interpret for themselves in ways that are beyond the control of any director, playwright, actor or artist. ${ }^{19}$ Thus we see Rancière drawing on the model of the audience-spectator relationship as being always to some extent inspirational rather than imitative.

More work needs to be done if we are to be able to read Rancière and Cavell together on this, for, at present, it seems that some important differences remain between the two thinkers. First, in contrast with my explanation above, Rancière states that this insight means that it is wrong to assume that spectators are passive until awakened by the knowledge imparted to them by others. Instead, he claims that the condition of the so-called passive spectator is our normal condition $^{20}$ and, furthermore, that such viewing is also an action. ${ }^{21}$ In the act of viewing, we link what we see and understand to what we have already seen and said, done and dreamed to weave it into the web that is our own individual life course. ${ }^{22}$ Furthermore, to see spectators as such is undemocratic, as it is based on an inequality that establishes two camps: the knowledgeable from the ignorant who are in need of this knowledge; the active thinker who must educate the passive spectator. This can become clearer if we supplement it with Rancière's The Ignorant School Master, where he suggests that such a division between the ignorant and the knowledgeable is the basis for all traditional pedagogy. This conveniently masks the inequality of power that it maintains between the two groups and thereby ensures the dominant position

${ }_{18}$ Rancière, "The Emancipated Spectator," p. 8.

${ }_{19}$ Rancière, "The Emancipated Spectator," pp. 14-15.

${ }^{20}$ Rancière, "The Emancipated Spectator," p. 17.

21 Rancière, "The Emancipated Spectator," p. 13.

22 Rancière, “The Emancipated Spectator," p. 13. 
of the knowledgeable. To make this argument, Rancière draws on the writings of nineteenth-century French pedagogue, Joseph Jacotot, ${ }^{23}$ who, whilst in exile during the French Restoration, developed a method called "universal teaching" whereby illiterate parents could teach their children to read. Following Jacotot, Rancière uses this method to challenge the traditional explicative teacher-pupil relationship, suggesting instead that teachers should not be conceived of as passing on knowledge, but of merely creating the conditions for students to learn. The success of this method is based on the assumption that all people are equally capable of learning for themselves, because "all men have equal intelligence." ${ }^{24}$ This can be used to challenge the inequality inherent in traditional teaching methods and thereby emancipate people without formal education from their dependence on "intellectuals."

The use of the term "emancipate" is important here. Rancière claims that when someone acknowledges the legitimacy of their own thought rather than that of another, this is emancipation. ${ }^{25}$ He later adds that emancipation can therefore be understood as the following: "that every common person might conceive his human dignity, take the measure of his intellectual capacity, and decide how to use it." ${ }^{26}$ If we take this back to the spectator relationship, then we see that if we are to be emancipated as a spectator then here too we need to trust our own judgment and not defer to another's interpretation. ${ }^{27}$ We need to be willing to accept our own translations of what we experience not by preventing film or other art forms from telling us stories, for "an emancipated community is a community of narrators and translators," but by all acknowledging their own ability to be "active interpreters, who develop their own translation in order to appropriate the 'story' and make it their own story." 28

\footnotetext{
23 Jacques Rancière, The Ignorant School Master: Five Lessons in Intellectual Emancipation, translated by Kristin Ross (Stanford, CA: Stanford University Press, 1981).

${ }^{24}$ Rancière, The Ignorant School Master, p. 18.

${ }_{25}$ Rancière, The Ignorant School Master, p. 13.

${ }^{26}$ Rancière, The Ignorant School Master, p. 17.

${ }_{27}$ Rancière, The Ignorant School Master, p. 13.

28 Rancière, The Ignorant School Master, p. 22.
} 
It is interesting to note that this would consequently indicate that, where Cavell mainly focuses on the value of remarriage comedies for democracy, Rancière leads us to be less restrictive, indicating that all films and all types of performance can play their role in our journeys of self-reflection. Indeed, if I turn back to my interpretation of the relationship between viewer and film above, we can see that in the final wedding scene of The Philadelphia Story the viewer is looking in on other viewers, the guests at the wedding. Although the guests only see the "perfect" wedding ceremony that Tracy and Dexter present to them, the viewer of the film sees more. The viewer's privileged position could be interpreted to mean that in all of life's experiences we can gain something from appreciating our perspective as onlooker on our society; by viewing the experience as if watching a film, looking on from a distanced perspective, we can think and reflect on our lives together from a critical distance. Hence, the practice of being a spectator engaged in the watching of a film, or viewing any work of art, is an exemplary relation (not necessarily the best, but a useful one) for our day-to-day lives that not only can but will inspire us in critical reflective thought.

Rancière further translates what this practice of emancipation entails, suggesting that, as emancipated spectators, we link what we see to that which we know in order to learn something new, "if we refuse, firstly, radical distance, secondly the distribution of roles, and thirdly the boundaries between territories." ${ }^{29}$ Ultimately, then, we are emancipated if we reject the vision of the world that we are told about by others and instead listen to our own thoughts. ${ }^{30}$ In noting this, I do not intend to go out of my way to read Rancière back to front, for I am aware that he is using the assumption of equality to challenge the notion of division of the social. I too share this aim, although by focusing on this passage it may seem I am trying to overturn it by substituting the division between the ignorant and the knowledgeable with a division between the emancipated and the unemancipated. However, there is a crucial

29 Rancière, “The Emancipated Spectator," p. 17.

${ }^{30}$ Rancière, "The Emancipated Spectator," p. 22. 
difference here, for the emancipated are not in a relation of power over the unemancipated because what they recognize - that all men are of equal intelligence - unites rather than divides. Yet this does mean that there are two ways of being a spectator. In neither is the spectator passive in the sense of not thinking. The crucial difference instead is whether she respects (and is expected to respect) the authority of her own interpretation or whether, in the unemancipated model, she submits her own interpretation (and is expected to do so) to the authority of others. Consequently, we perhaps need to revise the use of the terms "passive" and "active" above, such that, if perfectionism is to respect the logic of emancipation, we see the exemplar relationship as one that not only inspires response (for this will always be the case), but also encourages and accepts that the observer will trust her own thought rather than seek to imitate what is being shown.

Rancière refers to the state whereby we refuse to trust our own thoughts as one of "stultification" and "routine"31 and identifies a task for us in overcoming this in ourselves as well as in others: "any individual can always, at any moment, be emancipated and emancipate someone else, announce to others the practice and add to the number of people who know themselves and who no longer play the comedy of the inferior superiors." ${ }^{32}$ He thereby acknowledges a role for those he refers to as "the disciples" of universal teaching, who "announce to all individuals ... the way to teach what one doesn't know on the principle of the equality of intelligence." ${ }^{33}$ Such a disciple "does not teach a pupil his knowledge, but orders them to venture into the forest of things and signs, to say what they have seen and what they think of what they have seen." ${ }^{34}$ Although such a program of radical pedagogy and emancipation may at first appear to emerge from quite a separate tradition from the ethical focus of Cavell's moral perfectionism, it does not take much to find echoes of this emancipatory task in the writings of Emerson that

${ }^{31}$ Rancière, The Ignorant School Master, p. 108.

32 Rancière, The Ignorant School Master, p. 98.

${ }_{33}$ Rancière, The Ignorant School Master, p. 105.

${ }^{34}$ Rancière, "The Emancipated Spectator," p. 11. 
Cavell draws upon. In this sense, I see Emerson as one such disciple of universal teaching, and thus Rancière's work on emancipation supplements Cavell's moral perfectionism, suggesting that the latter model of exemplarity - whereby art inspires you to think for yourself - is more instructive than the former imitative model, not because it is a better way for people to act but because it is a more accurate description of how people already do relate to art. If we realize this, we understand better the role that films, as art, play in our social world. ${ }^{35}$ It is important if we are to draw parallels here, however, that I emphasize that, for Cavell, this holds as long as we do not understand Cavell, along with Emerson, telling people to think for themselves as opposed to not thinking, but understand that these passages summon people to trust their own thoughts rather than defer to the thoughts of others. This is invoked in Emerson's claim that "Man is timid and apologetic; he is no longer upright; he dares not say 'I think,' 'I am,' but quotes some saint or sage." 36 Thus, in relation to Rancière's understanding that an emancipated spectator relates everything they see and experience to the narrative of their own lives, it is important to return to Cavell's aforementioned discussion of exemplars ${ }^{37}$ to emphasize that perfectionism places less emphasis on the content of the interpretation of any film than on the act of interpreting itself, ${ }^{38}$ because each film can prompt independent reflection and thus will bring this value to the life of the person experiencing it. ${ }^{39}$

35 This is summed up in the sentence: "Truly speaking, it is not instruction, but provocation, that I can receive from another soul" (Cavell, Conditions Handsome and Unhandsome, pp. 37-8, citing Emerson's Divinity School Address).

36 Ralph Waldo Emerson, "Seal-reliance," in Selected Writings of Ralph Waldo Emerson (New York: Signet Classics, 2003), p. 279.

37 Cavell, Conditions Handsome and Unhandsome, p. 53.

${ }^{38} \mathrm{I}$ am not implying that interpretations are not of interest for what they can prompt in us, merely that I do not intend my interpretation of these films to be seen as rivaling Dienstag's or Cavell's, but to be complementary. Indeed, Cavell notes the importance of the interplay of interpretations for a person, interspersed with her own experience (Pursuits of Happiness, p. 36).

39 " $[\mathrm{T}] \mathrm{o}$ examine and defend my own interest in these films is to examine and defend my interest in my own experience, in the moments and passages of my life I have spent with them" (Cavell, Pursuits of Happiness, p. 7). 
For both Rancière and Cavell, interpretation of film is seen as an exercise in self-reflection and conversation with oneself, with one another and with one's society, where film is one inspiration amongst many that can be of use to us as we continually engage in the practice of revising and reapplying interpretations of the social to our own lives every day. Rancière's work has been useful in helping us to understand the power relations at stake in the two exemplar models encountered in this essay, to reveal that the model of imitation belongs to the explicative order of traditional pedagogy and unequal intelligences, whereas the inspirational model belongs to the emancipated order of universal teaching based on an assumption of equality. Furthermore, Rancière helps us to challenge Cavell's desire to draw only on "good" film ${ }^{40}$ and instead shows that all film is of value to the moral perfectionist life.

If we are to accept Rancière's suggestion that trusting the authority of our own thought will help us avoid reifying the inequality of intelligences, we nevertheless find little suggestion of how to cultivate such a practice and guard against accepting the authority of others' thoughts. Indeed, Rancière can be criticized for not thematizing democratic subjectification more thoroughly and so Cavell's work can be useful here to supplement Rancière. ${ }^{41}$ In particular, it is useful to return to the Emerson essays Cavell uses to thematize in more detail what it is that reflecting on films and other exemplars is meant to add to our lives and whether it is important for democracy.

\section{Dreaming for democracy}

In times when we thought ourselves indolent, we have afterwards discovered, that much was accomplished, and much was begun in us. ${ }^{42}$

40 Cavell, Cavell on Film, p. 334.

${ }^{41}$ I develop this argument more in Clare Woodford, Dis-orienting Democracy: Aesthetics, Knowledge and the Subject After Rancière (London: Routledge, 2016), ch. 3.

42 Ralph Waldo Emerson, "Experience," in Selected Writings, p. 351. 
[A] dream may let us deeper into the secret of nature than a hundred concerted experiments. ${ }^{43}$

A strange process too ... by which experience is converted into thought ... The manufacture goes forward at all hours. ${ }^{44}$

I wish in this section to revise why accepting the authority of one's own thought, hereafter referred to as "aversive thinking," is of value for democracy in order to defend the view that film, inasmuch as it is important for such thought, is therefore significant for democracy. It is first useful to recall, albeit briefly, what it is that aversive thinking comprises and how it can be accomplished. To begin with, Cavell argues that Emerson's writing shows how conformity captures our thought and expresses the claim that we need to become self-reliant by practicing an aversion to this, which will lead us to greater freedom. ${ }^{45}$ In Emerson's language, we each have an inner "genius," which we have to cultivate and follow rather than merely imitate others. ${ }^{46}$ By following our own genius and thinking aversively, we are enabled to conceive of life as an open-ended journey during which one is always seeking to develop the self, by never accepting the self as it is (the attained self) and always looking to the future to the next self, as yet unattained. When engaged in aversive thinking, it seems that the self is never satisfied and is always restless to develop; yet this state of affairs cannot come about in isolation, but relies on the perfectionist community of exemplars. Thus, this is not a solitary journey and can be achieved only through living "in conversation" with others both living and dead through the aforementioned consecration of one's heart to great $\operatorname{men}^{47}$ and also through conversation with one's own contemporary society, ${ }^{48}$ where conversation refers not just to speech but to a "way of life together." ${ }^{\text {" }}$ The figure

${ }^{43}$ Ralph Waldo Emerson, "Nature," in Selected Writings, p. 218.

${ }^{44}$ Ralph Waldo Emerson, "The American Scholar," in Selected Writings, pp. 233-4.

${ }^{45}$ Cavell, Conditions Handsome and Unhandsome.

${ }^{46}$ Cavell, Conditions Handsome and Unhandsome, p. 25.

47 See Cavell, Conditions Handsome and Unhandsome, p. 53.

${ }^{48}$ See Stephen Mulhall on the role of friendship for Cavell: Stanley Cavell: Philosophy's Recounting of the Ordinary (Oxford: Oxford University Press, 1994) p. 269.

49 Stanley Cavell, Cities of Words: Pedagogical Letters on a Register of the Moral Life (Cambridge, MA, and London: Belknap/Harvard University Press, 2004) p. 173. 
of the exemplar is central to this conversation where we learn from all others around us, be they friends, family, fellow-citizens, strangers, artists, authors or anyone; and, also, we need to remember that we too should live as exemplars to others to inspire them to be true to themselves. Further, it is clear that for Emerson the exemplar figure need not restrict us - indeed, it would seem that we can take instruction (on our own) from anything and everything - and every part of our lives is instructive since "the scholar loses no hour which the man lives." 50

Although Emerson seems to prioritize the lessons we can learn from the natural world over what we can learn from other humans, he does think that human exemplarity has its place. Consequently, we can articulate this relationship between one's thought and the arts as exemplar more precisely, in this passage from Emerson:

Man Thinking must not be subdued by his instruments. Books are for the scholar's idle times. When he can read God directly, the hour is too precious to be wasted in other men's transcripts of their readings. But when the intervals of darkness come, as come they must, - when the sun is hid, and the stars withdraw their shining, - we repair to the lamps which were kindled by their ray, to guide our steps to the East again, where the dawn is. We hear, that we may speak. The Arabian proverb says, "A fig tree, looking on a fig tree, becometh fruitful.".51

Thus, we can conclude that films can be a useful tool, but that is not to say that they are the best tool, nor that they will always be of value to us, but neither is it to say that we can overrule their potential to impart a valuable experience.

Consequently, it is important to remember that Cavell has argued that moral perfectionism is essential "training" for democracy. ${ }^{52}$ If we accept this argument, then seeing as we need exemplars to prompt us to always continue on this journey, and given that films can act as exemplars, it follows that they can comprise part of our training. Yet there is

50 Emerson, “The American Scholar," p. 236.

${ }^{51}$ Emerson, "The American Scholar," p. 231.

${ }_{52}$ Cavell, Conditions Handsome and Unhandsome, p. 56. 
a wider issue here beyond the issue of whether the comedies of remarriage, or film in general, may have some benefits for democracy, because Dienstag turns in the last section of his letter to express unease about the negative effects film may have on democracy. Before continuing, it is worth noting that Cavell has also noted that the type of cinema-going he invokes for moral perfectionism is a practice of a bygone day, and in many ways may not relate to the way in which we now frequent cinemas. ${ }^{53}$ In this respect, it may well be that Cavell would share some of Dienstag's unease. However, in relation to my argument that all film could in some small way be of value for democratic life, I would suggest that these concerns can be responded to from within the moral perfectionist register by turning back once more to Emerson.

In particular, Dienstag raises a few interrelated concerns in the final part of his letter with respect to films promoting a kind of dreamlike state which takes us out of our time and also out of our community, and thereby fails to enhance the important perfectionist quality of friendship and instead violently subordinates the unruliness of eros and passionate desire to a stifling order. In response to these concerns, I emphasize that the perfectionist practice of aversive thinking is a return to one's previously rejected thoughts. ${ }^{54}$ It is a reflective engaging practice in which the mind is never still. Thus, the time spent dreaming need not, and perhaps cannot, be neatly separated from our waking activities. Indeed, Emerson notes that our idle times ${ }^{55}$ and our dreams ${ }^{56}$ can often be more fruitful for perfectionism than time spent in other activities. Consequently, with respect to Dienstag's claim that our minds do not wander in the cinema, I can only claim from personal experience that this is not the case. Often the escape of the cinema provides a space away from the frantic hustle and bustle of daily life, where, whilst our bodies unwind and our buzzing minds start to slow, the deeper levels of

53 Stanley Cavell, The World Viewed: Reflections on the Ontology of Film (Cambridge, MA: Harvard University Press, 1979) p. 11.

${ }_{54}$ Cavell, Conditions Handsome and Unhandsome, pp. 54 and 59.

55 Emerson, "Experience," p. 351.

56 Emerson, "Nature," p. 218. 
our unconscious can also unfold to reflect upon our own interpretation of the events we see unfolding before us. Indeed, there is little chance in ordinary life today, beyond time spent in front of a screen, that allows time for such deep and reflective thought; yet, for the aversive way of life, time to think is clearly essential. In this sense leisure-time is necessary for aversive democracy and watching films is one of many forms of leisure activity that provide space for this. Accordingly, I wish to suggest that dreaming need not be quite as separate from democracy as Dienstag professes it to be.

However, Dienstag is also worried that such solitary leisure-time takes us away from our wider commitments to society and community-spiritedness. Yet, with regard to the solitude that we may encounter whilst in the cinema, it would seem that this can provide valuable space for somebody to develop their aversive thought, for "in the solitude to which every man is always returning, he has a sanity and revelations, which in his passage into new worlds he will carry with him. ${ }^{57}$ Hence, this activity should not be seen in competition with our commitment to society, for the physical time-out that it provides may re-energize us, give us time to think things through and therefore make us better citizens when we leave the cinema and re-enter the social world.

Furthermore, in the model of exemplarity that we find in Cavell, such solitude in the company only of exemplars need not take us into ourselves, but instead encourage us to be more than we are. Cavell contends that the exemplary films he writes about encourage us to have deeper, more responsive, relationships. Indeed, when watching films we get to see the perspective of others whose lives we can never share. We are made aware of other lives beyond our knowledge and understanding by these stories that take us beyond the confines of our own. Although it is true that we could well settle for the belief that we have experienced others' lives because we have watched a film about them which could limit our sensitivity to the concerns of others, such an

${ }^{57}$ Emerson, “Experience," p. 374. 
assumption does not fit with Cavellian perfectionism. This is made clear from Cavell's engagement with Rawls' Theory of Justice, ${ }^{58}$ in which Cavell notes that the perfectionist life is never "above reproach": one can never sit back and assume that one's democratic duty of responsiveness to others is fulfilled. Instead it requires that we see this responsiveness as an open-ended and never completed task. ${ }^{59}$

In this vein, although Dienstag is concerned that perfectionism stretches friendship beyond the possible, this does not mean that using friendship as an analogy for citizenship is a bad idea, for although it may be something we can never fully live up to, it does express the depth of the relationship that Cavellian perfectionism asks of democratic citizens, setting up such friendship as a valuable ideal to seek to attain, if only ever in part. Furthermore, if there is a possibility that access to cinema can be detrimental to our community-spiritedness, but films are simultaneously a valuable tool for democracy, then perhaps we need to ask more of ourselves and seek to be as friendly as the villagers that Dienstag encountered on the cycling holiday of his youth, whilst also having access to cinema.

Finally, then, to respond to Dienstag's concerns about eros and unruliness, it is helpful to begin by turning to his discussion of $\mathrm{La}$ Règle $d u$ jeu, which, he argues, is a "better, more honest teacher of social reality" (p. 49) than The Philadelphia Story. In his interpretation, this film reveals to us what happens when we try to control eros by subjecting it to a stable institution, in this case the institution of marriage: it leads to violence, anger, frustration and the final subdued scene of the Marquise, forced back to her husband's side with no hope of future escape. This leads him to suggest that the desire to control eros in any social institution, including democracy, can be dangerous, for it leads to suppression of people's spirit rather than the happiness called for by Cavell.

58 Cavell, Conditions Handsome and Unhandsome, ch. 2.

59 See also Clare Woodford, "From Nora to the BNP: Implications of Cavell's Critique of Rawls," British Journal of Politics and International Relations, 15:4 (2013): pp. 586-609. 
However, this is not the only interpretation of this film. It could alternatively show us the confusion of a woman so restricted by her own willingness to submit to social rules, despite her lonely marriage and confused feelings. Shocked awake by her husband's infidelity, she tries to rebel against the social order by throwing herself at anyone to find comfort and simultaneously settle the score with him; first setting her sights on her preferred accomplice (St. Aubin), whom, she confesses to her maid, she rather likes; when that fails, in panic she first takes advantage of André, who would do anything for her (although she thought he was boring), and then Octave, whom she knew cared deeply for her as they had been friends for so long. This film made me reflect on possible responses to betrayal. It indicated that any attempt at further manipulation and deceit can spin drastically out of control with disastrous consequences. It seemed to imply that it can be worth working at your relationship from the inside, rather than seeking to abandon it in the face of trouble. Consequently, for me, the principal difference between the two films was that, in The Philadelphia Story, the characters, especially the principal pair, communicate and learn together, whereas, in La Règle $d u$ jeu, the principal characters do not seem to think they have anything to learn, and certainly not to learn together, and thus play out their charade by destroying the lives of others around them. Hence, contrary to Dienstag, I would not argue that either film is "a better, more honest teacher of social reality," nor, in light of the above argument about imitation and inspiration, that either film is a more fruitful source of inspiration, for, as these counterinterpretations show, they will speak to people of different things in different ways.

However, I share my interpretation for a further reason, as Dienstag argued that film in general seeks to subdue eros with stability, to subordinate the democracy of moments to the republic of laws. It can portray this trade-off as inconsequential or costly, but will do so at its own risk. However, in my reading, film will only reflect the dance between eros and stability that underlies all of our social lives, yet it also reveals that there are various different ways to cope with this potentially 
antagonistic relationship: engage with it or ignore it (at your peril) ${ }^{60}$ In contrast, Dienstag suggests that, by giving eros free reign, we may be able to avoid the symbolic and often actual violence that emerges from the forced and cruel imposition of social order: "Perhaps there would be no families and no nations if eros were given free reign, but then perhaps there would be no Verduns and no Shoahs either" (p. 50). But, whilst admiring the sentiment behind this claim, I feel that it is to miss the symbiotic relationship between the two: we could not have the enjoyment of the disorder that eros brings if we did not know the sometimes stifling extent of a stable order, nor could we ever hanker after such stability if we had not experienced the confused exhaustion and insecurity of eros. Indeed, if eros were given free reign, what is to say that it would not become mundane and we would lose on all fronts. Instead, there is no easy way out of the conundrum. We have to learn to manage the relationship between the two and still avoid the violence that comes with either when pushed to extremes. We cannot avoid the need to work at our relationships, and it is here that I would suggest moral perfectionism can guide our way.

Returning Cavell to Emerson via Rancière helps us to reveal moral perfectionism as a compass to chart the path between eros and stability without stumbling too much toward either extreme. In each life the struggle between eros and stability is different. Furthermore, it is important to emphasize that the burdens and price one will pay to pursue this happiness and to live the perfectionist life will vary depending on one's material position and psychological disposition in a way that is often far from just, and in many cases requires urgent attention and action in the name of a responsive perfectionist citizenship. But this

${ }^{60}$ The reasons why La Règle $d u$ jeu "nearly instigated an armed revolt" are, for me, more likely tied up in the context of wartime France in 1938, where the protagonists are unpatriotically seen to represent desperate European countries, all leaping in and out of bed with one another in last-ditch attempt to avoid calamity. In the end, calamity strikes (André is killed) but the target (Marceau) is not hit; instead a more innocent victim (André) suffers, whilst the privileged instigators of the situation get off scot-free and survive to cause more disagreements in the future. Not a wonderfully patriotic picture to comfort a nation on the brink of war. 
is not to say that a flight of fancy, daydream or moment of realization whilst watching a film will not be of use in helping us imagine better worlds - in order to inspire us to work for them - where the obstacles to the pursuit of happiness are not so unequal.

\section{Conclusion}

At first, perhaps, it would appear that I do not agree with Dienstag. I do not think that instead of disappearing into the nearest multiplex to watch remarriage comedies, tragedies or other films we would necessarily always do better to envisage ourselves engaged in an open-ended citizenship quest that keeps our focus on the world around us rather than distracting us with "pretty stories," (p. 81). However, this is not because I think that Dienstag is wrong, merely that I think the terms of the debate needed to be clarified, for I do not believe we can separate the first activity so clearly from the second, nor that these stories can ever be just a distraction in the sense that they prevent us from thinking for ourselves. Instead, I think that time spent in the cinema can be of value to democracies in that it may, as may other leisure pursuits, help us to slow our thoughts and engage with our democracies more deeply by giving us time to pause and reflect on our own views, and perhaps become more emancipated citizens in the process.

It has, therefore, been suggested that the difference between Dienstag's and Cavell's readings come about in part because of the fact that neither distinguishes clearly between the imitative and the inspirational models of exemplarity, to emphasize that it is the latter that may be more beneficial for democracy whilst the former can be detrimental. This means that the differences in their readings of film are then compounded by Dienstag's more cynical outlook in contrast with Cavell's insistent commitment to happiness despite the way that our "obligations and compromises of adulthood begin to obscure the promise and dreams of youth and the rift between public demands and private 
demands comes to seem unbridgeable." ${ }^{61}$ But, this is to be celebrated rather than bemoaned for, in questioning Cavell's unstinting commitment to happiness, the limits, burdens and responsibilities of moral perfectionism are revealed and laid open to scrutiny and assessment, which help to clarify what it can offer our democracies today. Thus I am able to suggest that by choosing the aversive path, but with a more precise understanding of the role of exemplarity within this, we may begin to address the disadvantages and inequality of burdens in the deep and ever more responsive way that perfectionist democratic life entails. And so, taking moral perfectionism as our compass and pausing to dream as we travel, I hope we can embark on Dienstag's quest, navigating our way between eros and stability, in pursuit of the happiness that is the promise of an emancipated perfectionist democracy.

${ }^{61}$ Cavell, Cavell on Film, p. 11. 